\title{
Medieval marriage and superstitions
}

\author{
Lesley Smith
}

Curator, Tutbury Castle,

Tutbury, UK

\section{Correspondence to}

Ms Lesley Smith, Tutbury

Castle, Tutbury, Staffordshire

DE13 9JF, UK;

info@tutburycastle.com

Received 31 October 2011

Accepted 3 November 2011

\section{Financial considerations}

Whatever her rank through birth, a woman in the early medieval period was obliged by Anglo-Saxon law to live under the lordship of a man described as her mundbora; a modern translation would be 'protector'. The father was the natural protector of his children, and in the case of daughters would continue to be so until her marriage, when the responsibility would pass to her new husband.

If her father died before she was married then her brother would take on the responsibility, and in the case of his death it would pass to her male kin; if none survived she would come under the direct protection of the King.

The new bride could be literally bought and the value of a woman was determined both by her rank and also by her marital status at the time of marriage negotiations. For example, a widow was worth approximately half as much as a virgin of the same rank. A widow could find times particularly difficult as the law of King Canute prohibited her to remarry until 12 months had passed since the death of her husband or the money paid for her would pass back to her late husband's family; in such a case she would be likely to have very little to offer in terms of fortune to a new husband. Henry I made this law of Canute not just a tradition but part of the fabric of the English marital legal system.

The giving of gifts to the newly married couple was well established, as was the literal 'giving away' of the woman to the new husband by her mundbora with the words: "I give thee my daughter, to be thy honour and thy wife, to keep thy keeps and to share with thee bed and goods". In a modern ceremony, whether church or civil, we usually hear the words: "Who gives this woman...?".

The considerable value society placed on a virgin can be found as early as the law of King Ethelbert, which stated that a bridegroom may return his bride to her family and demand his purchase price back if she were not of the virgin state. A lost hymen could cost a girl not just her reputation as a god-fearing, modest girl but also money taken from her family coffers, so one can imagine that she would not have a warm welcome when taken back into the family household after rejection.

Any individual who took the virginity of a girl was obliged to marry her, and if her father would not accept him as a new son-in-law then he had to pay a fine to her family of her marriage value. Women would then be referred to as 'spoiled goods', a term that is still used today. This idea of selling women in marriage continued in some sectors of society until the 19 th century, when records show women were bought for as much as 25 guineas or as little as half a pint of bitter beer.

A woman and her goods, once given in marriage, were literally owned by the husband, although her soul remained in the possession of God. The modern observer would be right to assume this would result in many incidents of brutality and even the murder of some women, but the man would be answerable to the criminal and ecclesiastical courts for such actions. There are also, happily, some interesting and amusing cases such as Honor L'Isle, a grand aristocrat who was a very tough character indeed and who, it seems, rather ruled the household, including her husband, with an iron fist.

\section{Marriage preparations}

In previous Journal articles I have described what society expected of a married couple and how from the earliest age a young girl would know that her one main purpose was to marry and bear children, particularly boys. These young people were taught that they should model themselves on their parents and ancestors and work within the universe that medieval man saw as entirely set up by God for the purpose of a great plan with a sympathetic relationship between all the parties involved.

Preparations for marriage among all strata of society were as elaborate as purses 
would allow and were an opportunity for families to display wealth and fashionable style. Even the poorest peasants would seek to bring family and friends together to eat, drink and be merry, even if only in a modest way.

It was not uncommon among the great families for the marital couple to meet for the first time on the actual wedding day of their arranged marriage. It must have been a terrifying prospect for some of the youngsters, not least because some were married to individuals with very substantial age gaps; a girl as young as 14 years of age could be married off to a rich merchant in his fifties. The lure of a fertile young body able to bear children for a powerful family was irresistible to many, with children being used as valuable chess pieces on the board of commerce and politics.

Priests were not always present at a medieval wedding and did not have to be by law until the reign of Mary I in the mid-16th century. Marriage did not become a sacrament in its own right until 1446 after the Council of Florence, and then there was a time gap before the law insisted on a priest being present at weddings taking place in England.

After this, banns became essential and a licence to marry had to be obtained. Marriage in the holy season of Lent could result in excommunication for the couple unless a special licence was obtained, usually from a bishop. Hurried weddings could also be allowed with only one bann reading with a special licence from a bishop; this was the case for the marriage of the 18-year-old William Shakespeare and his 26-year-old pregnant bride, Anne Hathaway.

A procession to the marriage was expected so that the local community could have a chance to enjoy the spectacle and also raise any concerns they might have; this is where the objection part of the current ceremony still remains in religious and civil ceremonies. The marriage group with blushing bride walking through cheering crowds and excited naughty boys making a nuisance of themselves can be seen in late Victorian paintings. The throwing of flowers or rice after the wedding is obviously symbolic of fruitfulness.

If the medieval bride was called Mary (named after the Virgin Mary) then she would wear blue and carry flowers and very often have a coronet of flowers around her head. Symbols of fertility such as wheat were commonly seen at harvest-time weddings or dried out and stored from an earlier season.

\section{Marriage superstitions}

The fear of dark magic, particularly witchcraft, was uppermost in many minds and there are many superstitions associated with the marriage ceremony and nuptial bed. It seems that society believed that Satan was trying to cause chaos by working against God's plan and that plan included marriage. This meant brides and grooms could feel vulnerable and steps were taken to protect them from perceived evil intent.
The bride would usually be accompanied by other women or girls dressed the same as her to confuse evil spirits on the journey, and candles were lit to provide light and cleansing fire. The tradition of the veil over the face was originally to hide the identity of the bride and not to cover her blushes. The concept of the white wedding dress is a modern concept; previously brides and grooms wore their best clothing for the ceremony.

Music was usually played and dancing would take place after the wedding feast, although there was much disapproval among the pious. Dancing, for some reason, was associated with the Devil for centuries and believed by some to attract evil spirits. According to contemporary witnesses, a witches' Sabbat was filled with music and dancing.

After the feasting was over, the groom would be taken from the table by cheering male friends and prepared for the bedchamber while the bride would be taken by her female attendants for undressing. Reluctance by the bride would demonstrate a suitably feminine and modest state. She would be undressed and put in a light shift, which could be linen (or even silk for the rich) and often decorated with flowers or religious symbols. The bride would be put to bed and then her new husband was brought in by his attendants. He too would be wearing a shift, which was the night-time attire for both sexes.

During the course of the day, the more superstitious might ensure the bed be checked for veneficium (i.e. poisonous or magical) objects placed there by those with malicious intent. These items of evil could take the form of a knotted rope to ensure the groom had erectile dysfunction, small human bones taken from corpses, and perhaps the skin or hair of an animal that could cause severe illness or even death. Servants were sometimes arrested for depositing such objects in a mattress. These servants were often in the pay of a rival household or perhaps held a grudge against the family. It is important to understand that society believed absolutely that such objects, charmed by a witch in league with the Devil or his demons, could cause great harm. This obsession with witches became really heated in the late medieval period and carried on in one hysterical form or another for centuries.

\section{Bedtime rituals}

Once the young couple were in bed with their family and friends gathered around them, the bed was blessed and prayers might be said. Then the bride would reach under the covers and remove one of her stockings and throw it into the crowd. The person who caught it would be the next to marry. Later a bouquet would be thrown.

Finally, for the richer couple, the curtains would be drawn around the bed and some time and privacy at last was available to them to get used to each other's bodies. Not everyone enjoyed privacy, however, as among the higher levels of society intercourse was 
witnessed and recorded, often by an ambassador, to be sure that the marriage contract was complete. The case of Henry VIII and his first wife, Katherine of Aragon (previously married to Henry's elder brother, Arthur, who died as a young man before becoming king) reminds us of how important witnessing consummation could be. Clearly, witnessing was not always the case or we would know if Katherine was a virgin as she claimed when she married Henry and that fact would be pivotal. It is still unproven, although the papal bull, published to allow Henry to marry Katherine, interestingly states that intercourse probably took place.

No doubt intercourse was as varied according to the experience of the individuals as it is now. The church was clear that only what is now described as 'missionary fashion' was appropriate as all other positions were considered either able to avoid conception with semen falling from the body (woman astride the man) or just bestial (on all fours from the rear).

They would try to have the bed chamber hot as men were believed to be hot by nature and that would encourage the conception of a boy. Hot food such as red meat and spices may have been consumed as part of the wedding feast for the same reason.

Finally, the bride must not lie back and think of England. Ideally she should think of nothing, as that might influence the health and looks of the child she might conceive that night.

\section{About the author}

Lesley Smith is currently a postgraduate student in the Centre for the History of Medicine of the
University of Birmingham, where she is developing a $\mathrm{PhD}$ in obstetrics and gynaecology in early modern Britain. She holds an honorary degree for "services to history". She makes 200-300 public appearances a year and also works as a TV historian in the UK and abroad including the USA. Lesley is also Curator of Tutbury Castle in Staffordshire and is a member of the Society of Apothecaries of London and the Society of Medical Writers. She has recently been appointed a Fellow of the Society of Antiquaries of Scotland.

Acknowledgement The author would like to thank Dr G Williams, British Museum, London, UK for his help and advice.

Competing interests None.

Provenance and peer review Commissioned, internally peer reviewed.

\section{Further reading}

1 Maxwell-Stuart PG. Witch Hunters: Professional Prickers, Unwitchers and Witch Finders of the Renaissance (2nd revised edn). Stroud, UK: The History Press Ltd, 2005.

2 Hawkes J. Sex in History. London, UK: Thames and Hudson, 1959.

3 Bloch I. Sexual Life in England Past and Present. London, UK: Oracle Publishing, 1996.

4 Gaskill M. Witchfinders: A Seventeenth-Century English Tragedy. Cambridge, MA: Harvard University Press, 2005.

5 Gowing L. Common Bodies: Women, Touch and Power in Seventeenth-Century England. Newhaven, CT and London, UK: Yale University Press, 2003. 